\title{
The making of conservation Action Plans for the Galliformes
}

\author{
P. McGOWAN, R. W. R. J. DEKKER, S. DOWELL and P. GARSON
}

\begin{abstract}
Summary
Megapodes: an action plan for their conservation 1995-1999 was published in 1995 by the Species Survival Commission of IUCN - The World Conservation Union. It is the twenty-eighth publication in its Action Plan series and the first for any group of birds. Action Plans published under the auspices of the Species Survival Commission are perceived as a means of making information on the status, threats and action required to safeguard species available to conservation planners and others in a position to take action. They are compiled by the appropriate taxon Specialist Group of the Species Survival Commission and their production and implementation is central to the Commission's activities. As well as the megapodes, Action Plans have recently been compiled for the partridges, quails, francolins, snowcocks and guineafowl, and for the pheasants. Stimulating interest in the conservation of these three groups of birds is the responsibility of three Specialist Groups which operate under the joint parentage of the World Pheasant Association, BirdLife International and the Species Survival Commission. The World Pheasant Association is the umbrella organization for five Galliformes Specialist Groups and was the driving force behind the production of these Action Plans, providing the means for the Specialist Groups to compile the information. This paper outlines the scope of these Action Plans and explains how they were compiled in the hope that this may assist the production of Action Plans for other bird groups.
\end{abstract}

\section{Introduction}

The Species Survival Commission of IUCN - The World Conservation Union has promoted the production of Action Plans since 1986. Their compilation and implementation is one of the Commission's major activities (Giminez-Dixon and Stuart 1993). This series now contains more than 30 such plans, the aim of which is to assess the nature and scale of threat to particular species or groups of species and to propose conservation action that should lead to a safer future for the species of concern. To date, most Action Plans have addressed the conservation needs of mammals, especially high-profile ones, such as primates (Oates 1986, Audey 1987, Mittermeier et al. 1992) and elephants (Cumming et al. 1990, Santiapillai and Jackson 1990). No Action Plan had been published for any group of bird species until spring 1995, when Megapodes: an action plan for their conservation 1995-1999 (Dekker and McGowan 1995) appeared. Presumably this is partly due to the voluntary nature of the Specialist Groups which draft these plans and which are comprised of people who, whilst dedicated to the conservation of the species in which they are interested, are also in full-time employment in other capacities. In addition, most global species conservation statements about birds 
have been made through the long-standing emphasis on Red Data Books, compiled by the International Council for Bird Preservation (ICBP - now BirdLife International) in collaboration with IUCN (Vincent 1966-1971, King 1978-1979, Collar and Stuart 1985, Collar et al. 1992) and the interim publications, Birds to watch (Collar and Andrew 1988, Collar et al. 1994, see also Collar 1994).

Efforts by the Species Survival Commission to promote the compilation of Action Plans by all Specialist Groups that operate on its behalf coincided with the formalization of a Specialist Group structure within the World Pheasant Association (WPA), an organization committed to the conservation of the Galliformes and their habitats. This umbrella organization now works with five such groups.

The World Pheasant Association has produced a biennial Conservation strategy since 1982. This internal document outlined priorities for conservation action and was updated at two-yearly intervals. By the early 1990 it was apparent that this document was insufficient as a guide to what actions were required on behalf of the world's Galliformes (= Gallomorphae sensu Sibley and Monroe 1990). At the same time, the Species Survival Commission invited WPA to prepare Action Plans for publication in its Action Plan series. Given the number of species involved (about 270 for all Galliformes), it was felt to be most appropriate to produce Action Plans for each major group of species: cracids; grouse; megapodes; partridges, quails and francolins; and pheasants (S. N. Stuart in litt. to K. C. R. Howman 1991).

As the Action Plans for the last three groups are the first to be produced for birds, here we introduce the Specialist Groups and outline how the plans were compiled, indicating our guiding principles. We also summarize the content of the plans, in the hope that this will promote interest in the conservation of these species and their habitats. Our experience may be of interest to those contemplating the preparation of global conservation strategies for other taxonomic groups.

\section{The Specialist Groups and their species}

Each of the three groups of species covered here is easily recognizable, but their relationships to one another have been the subject of much discussion. An overview of higher-level taxonomy amongst birds can be found in Sibley and Ahlquist (1990). As the Action Plans are concerned with identifying species or subspecies of concern, a decision on nomenclature had to be made at an early stage. For the purposes of consistency with BirdLife International, the species list proposed by Sibley and Monroe (1990) was followed for partridges and pheasants, despite the limitations of this list. We followed Jones et al. (1995) for the megapodes.

The Megapode Specialist Group was established in 1986 after the symposium on Mechanisms of very early development in animals and man, organized by the late Professor Klaus Immelmann at the University of Bielefeld in Germany as a means of maintaining contact between megapode researchers. With time, the group became aware of the considerable threat to these species and links were established with WPA and the Species Survival Commission as a way of promoting their conservation. We take the megapodes to include 22 species (Jones et al. 1995) which comprise the family Megapodiidae. 
The Partridge, Quail and Francolin Specialist Group was created in late 1991 after the First International Partridge, Quail and Francolin Symposium (Birkan et al. 1992) hosted by The Game Conservancy Trust in the U.K. The species covered by this Specialist Group are commonly known as partridges, Old World quails, New World quails, francolins, snowcocks and guineafowl. There are 106 species of Old World partridge, quail, francolin and snowcock, 31 species of New World quail and six species of guineafowl (Sibley and Monroe 1990). This includes the Udzungwa Forest Partridge Xenoperdix udzungwensis discovered in 1991 (Dinesen et al. 1994). For brevity in this account, we use the generic term "PQF" to include all species covered by this Specialist Group.

The Pheasant Specialist Group was the last of these three groups to be created, in June 1993. It was formed to provide a focus for the preparation of the Action Plan for these species and simultaneously relieved the WPA of much work. The species for which the Pheasant Specialist Group is responsible belong to a single family, the Phasianidae. There are 51 species (Sibley and Monroe 1990).

There are two other Galliformes Specialist Groups. The Cracid Specialist Group developed out of the Cracid Working Group, and the Grouse Specialist Group has only just been set up. Compilation of material for Action Plans for these two groups was not attempted at the same time as the three covered above for practical reasons.

\section{Action Plan compilation}

Aim

An Action Plan needs to be action oriented and so should not be a comprehensive account of faunistics and ecology. Details of species biology and exhaustive reviews are best covered elsewhere as this is not the information that conservation managers require from such an action oriented document. The plans should, therefore:

- present practical advice that is easily accessible

- provide the most up-to-date assessment of status

- and, most importantly, explain the work that needs to be done to ensure the survival of the most threatened species.

Every effort was made in these three cases to gather this knowledge from published and unpublished material, correspondence and verbal communication with all those involved in research and conservation of the species assessed. Consequently, each document represents years of gathering information, which was presented in a standard format and widely reviewed before publication. The compilation included the formulation of ambitious but realistic five-year plans of action, in the form of specific projects which will, if achieved, play a major role in conserving these species and their habitats.

\section{Procedure}

The identification of projects for inclusion in these five-year plans of action, which are essentially the conservation programmes of each Specialist Group for the period 1995-1999, was made in three steps: 
(i) Collation of data, identification of threats, assignment of threat categories and the proposal of action. This was done for each taxon considered worthy of separate attention and is presented in a Conservation Assessment Table in each plan.

(ii) Compilation of additional information on threatened taxa, including current distribution, occurrence in protected areas and captive population size. This information is presented as a Threatened Taxon Summary for each such taxon.

(iii) Determination of priority projects that are urgent and can be initiated within, or continued during, the period 1995-1999. Outlines are presented for each of these projects as Action Plan Project Briefs.

Each of these steps is the subject of a chapter in the Action Plans, the last one being the conservation programme of each Specialist Group for the five-year period. As a background to each Action Plan the introductory chapter details its scope, explains its compilation, and summarizes the threats to that group of species and the types of action needed to mitigate them.

\section{Biological principles}

Specialist Groups deal with species and subspecies and Action Plans present conservation programmes for these taxa. Given the scale of the threat facing species and the scant resources available to counter these threats, some sort of prioritizing inevitably takes place. The starting point for the assessment of the most urgent priorities for conservation action was a review of all available information on the status of the species concerned. In assessing the status of all species, two questions had to be answered. First, which taxa should be considered: i.e. were there any situations in which it was appropriate to consider subspecies in particular; and second, how could the degree of threat to all assessed taxa be indicated in such a way as to allow valid comparisons between taxa to be made so that priorities could be set?

\section{Consideration of subspecies and subspecies clusters}

In some cases subspecies were thought worthy of attention either on their own or as a group within a species. There were two reasons for subdividing species into subspecies or clusters of subspecies:

(i) Geographical isolation where this is related to morphological differences, such as occurrence on an island (e.g. the Hainan Grey Peacock-pheasant Polyplectron bicalcaratum katsumatae from Hainan Island in China. This taxon is considered as a separate species by some authors).

(ii) Belief that subspecies are facing threats that are different in nature or scale to the rest of the species. This consideration led to taxa below the species level being treated separately in four cases:

(a) if the rest of the species was widespread and believed to be fairly safe, but some subspecies were not (e.g. some subspecies of the Silver Pheasant Lophura nycthemera). 
Table 1. Number of taxa assessed for threat in three Galliformes Action Plans.

\begin{tabular}{lcccc}
\hline Specialist Group & No. species & $\begin{array}{c}\text { No. undivided } \\
\text { species }\end{array}$ & $\begin{array}{c}\text { No. subspecies } \\
\text { or subspecies } \\
\text { clusters }\end{array}$ & $\begin{array}{c}\text { Total no. } \\
\text { taxa } \\
\text { assessed }\end{array}$ \\
\hline Megapode & 22 & 19 & 6 & 25 \\
PQF & 143 & 136 & 15 & 151 \\
Pheasant & 51 & 38 & 32 & 70 \\
Total & 216 & 193 & 53 & 246 \\
\hline
\end{tabular}

(b) if various subspecies of a clearly threatened species were thought to face different conservation problems or require different remedial action (e.g. the three subspecies of the Scaly-breasted Hill-partridge Arborophila charltonii);

(c) only one of two subspecies was thought threatened (e.g. the Misol subspecies of the Wattled Brush-turkey Aepypodius arfakianus misoliensis);

(d) if a geographically widespread species was considered to comprise two or more clusters of subspecies which were believed in need of special attention (e.g. subspecies clusters of the Blood Pheasant Ithaginis cruentus).

The species was considered to be the unit for consideration (i.e. threat categorization) unless it was thought that there were compelling reasons for such subdivision. This process resulted in threat categories being assessed for 246 taxa in 216 species. This included 40 subspecies treated separately, 13 clusters of two or more subspecies and 193 undivided species (Table 1).

\section{Threat categorization}

In order to identify the taxa most urgently in need of attention, a ranking system that reflects the degree of threat to each taxon is clearly required. IUCN threat categories were deemed the most appropriate categories to apply because they are designed for global use and are broadly accepted among the international conservation community. The categories represent increasing risks of extinction and have recently been revised. Under the original system Endangered was assigned to those taxa most at risk, Vulnerable to those less so and Rare to taxa which are threatened, but not as seriously as those thought to be Endangered or Vulnerable (Groombridge 1994). Other categories included Extinct, Indeterminate, Insufficiently Known, and Commercially threatened. Despite limitations, this system provided a means of attracting attention to species threatened with extinction in varying degrees and, increasingly, as a means of allocating the scarce resources available for conservation action.

Increasing use of the IUCN threat categories for prioritizing among species in need of conservation action has led to recent efforts to define the categories more objectively (Mace and Lande 1991). The initial proposal, now referred to as version 1.0, of this redefinition was published in 1991 (Mace and Lande 1991). Version 2.0 (Mace et al. 1992) was finalized only just before the preparation of these three Action Plans began in early 1993. General familiarity with version 1.0, 
which was widely known through its publication in Conservation Biology, and its use in Conservation Assessment Workshops run by the Conservation (formerly Captive) Breeding Specialist Group, convinced us to use it to assign threat categories to our taxa at that time. It was apparent at that time that achieving a consensus across the international conservation community on the new IUCN threat category system was going to be a lengthy process. This was indeed the case with version 2.3 being finally adopted by IUCN in November 1994.

It should be noted that the threat categorization made by the BirdLife International Secretariat in Birds to Watch 2 (Collar et al. 1994) used the criteria of version 2.2. Differences in threat assignment between the Action Plans and Birds to Watch 2 are more likely to be a consequence of different opinions on the degree of threat to particular taxa, rather than of differences in the criteria between versions 1.0 and 2.2.

\section{Conservation Assessment Workshop}

The development of these Action Plans was centered on the Conservation Assessment Workshop for the Galliformes held in Antwerp, Belgium during the first week of February 1993 (McGowan et al. 1994).

\section{Background}

The Conservation Breeding Specialist Group of the Species Survival Commission has conducted many Conservation Assessment Workshops recently, usually in collaboration with one or more of the other taxon Specialist Groups. Conservation Assessment Workshops on bird groups have recently covered waterfowl (Ellis-Joseph et al. 1992) and pigeons and doves (Toone et al. 1993) amongst others. The object of these intensive meetings is to attempt a rapid review of status, threats and action required.

\section{The Galliformes Workshop}

The WPA and the three Specialist Groups involved collected many of the data required in advance of the workshop by compiling Conservation Assessment Tables (Figure 1 and Table 2). Discussions at the workshop were organized on a regional basis, with groups of participants concentrating on: South-East Asia and Australasia; China and South Asia; Europe, the Middle East and Africa; and the Americas. A number of species occurred in two of these regions, and some even in three: these were discussed jointly. The Conservation Assessment Table was the basis for discussions at the workshop (Table 3). Full details of the conservation assessments made and projects identified are given in the Action Plans (Dekker and McGowan 1995, McGowan et al. 1995, McGowan and Garson 1995).

\section{Identification of projects for the plans of action}

Future conservation action was considered for all taxa included in the Conservation Assessment Table. These actions were explained further for all threatened and poorly known taxa in the Threatened Taxon Summaries (Table 4). Based on 
PROCEDURE

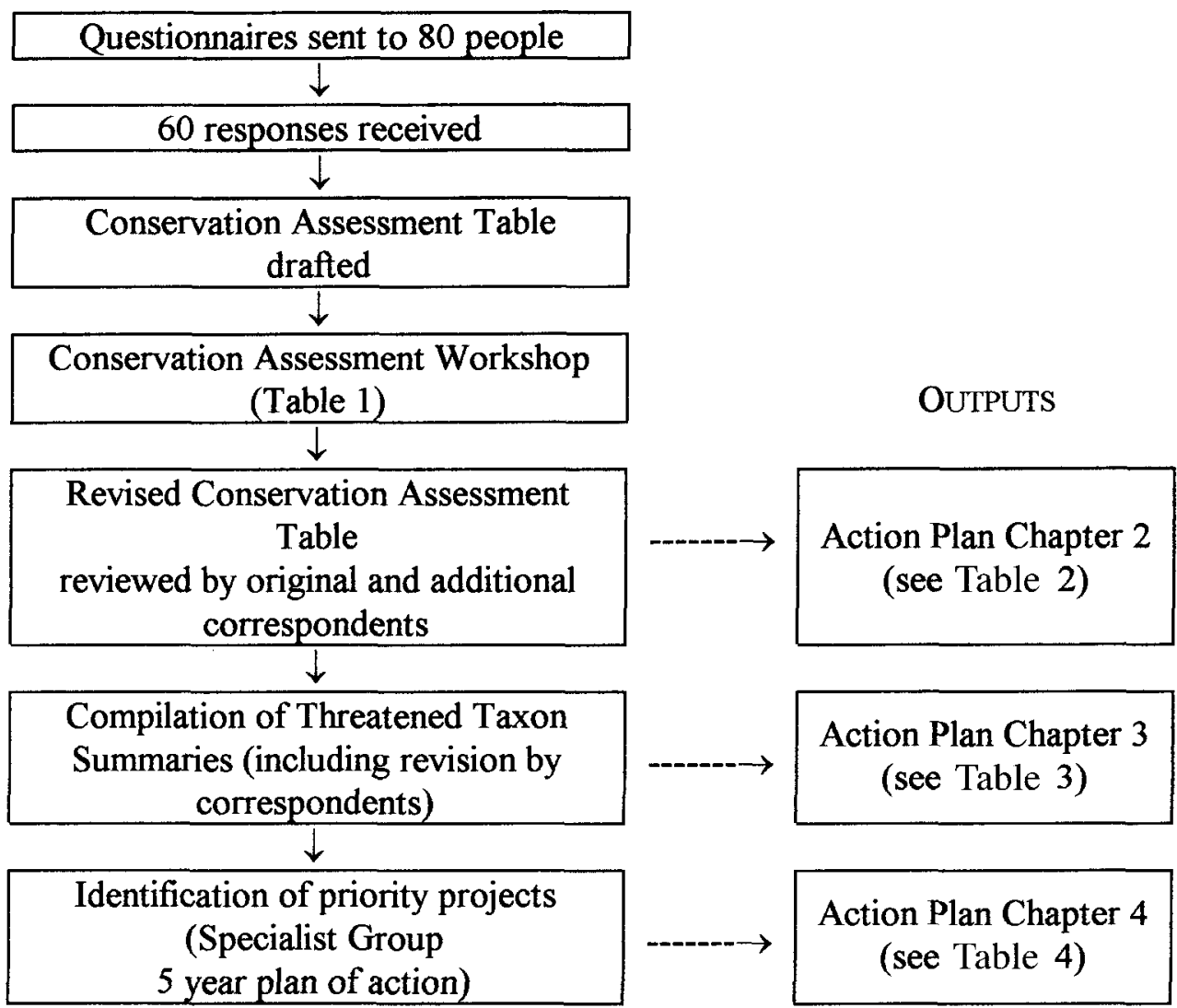

Figure 1. Procedure for compiling and reviewing information for the status survey of Galliformes and the identification of priority projects given in the Action Plans

Table 2. Example of two entries from the Conservation Assessment Table in the Pheasant Action Plan. Range area D, continental range between 500000 and $1000000 \mathrm{~km}^{2}$; Population trend D, declining; M-L cat. V, Mace-Lande threat categorization of vulnerable

\begin{tabular}{|c|c|c|c|c|c|c|c|}
\hline $\begin{array}{l}\text { Scientific name } \\
\text { English name }\end{array}$ & $\begin{array}{l}\text { Sub } \\
\text { spp }\end{array}$ & $\begin{array}{l}\text { Range } \\
\text { area }\end{array}$ & $\begin{array}{l}\text { Range } \\
\text { countries/ } \\
\text { regions/ } \\
\text { islands }\end{array}$ & $\begin{array}{l}\text { Pop. } \\
\text { trend }\end{array}$ & Threats & $\begin{array}{l}\text { M-L } \\
\text { cat }\end{array}$ & Future actions \\
\hline $\begin{array}{l}\text { Lophua diardi } \\
\text { Siamese Fireback }\end{array}$ & - & $\mathrm{D}$ & $\begin{array}{l}\text { Cambodia, } \\
\text { Laos, } \\
\text { Myanmar, } \\
\text { Thailand, } \\
\text { Vietnam }\end{array}$ & $\mathrm{D}$ & $\begin{array}{l}\text { Habitat loss, } \\
\text { hunting }\end{array}$ & $\mathrm{V}$ & $\begin{array}{l}\text { Control hunting } \\
\text { Habitat } \\
\text { management } \\
\text { Survey }\end{array}$ \\
\hline $\begin{array}{l}\text { Crossoptilon } \\
\text { crossoptilon } \\
\text { White-eared Phea- } \\
\text { sant }\end{array}$ & 4 & D & China & D & $\begin{array}{l}\text { Habitat loss, } \\
\text { hunting }\end{array}$ & V & $\begin{array}{l}\text { Control hunting } \\
\text { Habitat } \\
\text { management } \\
\text { Survey }\end{array}$ \\
\hline
\end{tabular}


Table 3. Main tasks undertaken during the Galliformes Conservation Assessment Workshop

\begin{tabular}{ll}
\hline No. & Description \\
\hline 1 & $\begin{array}{l}\text { Revision of the information in the Conservation Assessment Table and assessment of its } \\
\text { reliability, including the division of species into subspecies or subspecies groups }\end{array}$ \\
& $\begin{array}{l}\text { Amalgamation or subdivision of information (e.g. on population size) supplied from differ- } \\
\text { ent range countries for each taxon recognised in } 1 \text { above }\end{array}$ \\
& Compilation of information on known captive population sizes of each taxon from the 1992 \\
World Pheasant Association captive census and the 1992 International Species Identification \\
System records \\
Assignment of a threat category on the basis of the Mace-Lande criteria (Mace and Lande \\
1991) to each taxon recognized in 1 above \\
Recommendation of future action for all taxa judged to be threatened with extinction or \\
which are poorly known. Action was considered for some other taxa, especially where \\
there is an evident need for taxonomic clarification of specific or subspecific status \\
Consolidation of information on threatened taxa into "Threatened Taxon Summaries" to \\
justify threat categorization and specify necessary action
\end{tabular}

Table 4. Example of a Threatened Taxon Summary from the Megapode Action Plan. Taxonomy in this plan follows Jones et al. (1995)
3.14: Tanimbar megapode Megapodius tenimberensis
Conservation status: Mace-Lande: Vulnerable
CITES: Not listed

\begin{tabular}{ll}
\hline Taxonomic status & A monotypic species which was formerly considered a subspecies of M. reinwardt \\
$\begin{array}{l}\text { Current } \\
\text { distribution }\end{array}$ & $\begin{array}{l}\text { Tanimbar Island (very restricted range). Split from } M \text {. reinwardt since the Biodiv- } \\
\text { ersity Project (see ICBP 1992) was completed. It does, however, have a restricted } \\
\text { range and occurs in Endemic Bird Area E18, which is Tanimbar and associated } \\
\text { islands and is a Priority 1 Endemic Birds Area }\end{array}$ \\
Threats & $\begin{array}{l}\text { Predation by introduced predators, hunting, egg collection and habitat degrada- } \\
\text { tion by humans }\end{array}$ \\
Future action & $\begin{array}{l}\text { A proposed nature reserve covers approximately half of the island. The current } \\
\text { status of this reserve needs clarification. A survey within the proposed nature } \\
\text { reserve as well as some of the surrounding islands is needed. See project }\end{array}$ \\
\hline
\end{tabular}

all of this information, and further discussion within the Specialist Groups and with others, project outlines were developed. These were called Action Plan Project Briefs (Table 5) and make up the five-year plan of action that each Specialist Group is seeking to implement (Figure 1). As such they are the essence of the Action Plans.

Projects were identified according to slightly different criteria depending upon the group of species concerned. The Megapode Specialist Group used the three criteria of urgency, quantity and quality of existing information, and the size of the taxon's range. This meant that projects were included simply on the basis of perceived conservation need. Urgency was based upon the threat criteria assigned and all threatened taxa were considered for inclusion. The quality and quantity of information was used to promote action for taxa which are especially poorly known. Given that the majority of megapodes occur on small islands, the size and dispersion of these islands was also considered. In combination, the last 
Table 5. Example of an Action Plan Project Brief from the Partridge, Quail, Francolin, Snowcock and Guineafowl Action Plan

Status and conservation of the Bearded Tree-quail Dendortyx barbatus in Mexico

Mace-Lande status: Critical

Aim: Conservation of a viable population of the Bearded Tree-quail and the development of conservation management plan.

Justification: The Bearded Tree-quail is a critically threatened Restricted Range Species (ICBP unpublished data; see ICBP 1992) dependent on a small area of humid montane forest in the Sierra Madre Oriental in Hidalgo and Veracruz, Mexico where forest loss continues at a rapid rate. Most of the documented populations are old, and habitat in many of these areas has been destroyed as a result of forest clearance (Collar et al. 1992). There have been few sightings since the 1960s. An immediate priority is the location of any extant population and the urgent development of a management plan in the light of survey findings, given the rate of forest loss

Project description: The following should be carried out:

1. Locate patches of suitable habitat, perhaps through initial aerial and satellite mapping

2. Survey the habitat to locate extant populations, estimate size, area of remaining habitat and assess a degree of threat

3. Carry out management workshop (Population and Habitat Viability Assessment) involving local agencies to identify viable populations and their conservation requirements

4. If wild populations are considered to be not viable then a captive programme might be proposed to minimise the risk of extinction

Time scale: Five years

Budget: $\$ 50000-\$ 100000$

\section{Suggested reading:}

Collar, N. J., Gonzaga, L. P., Krabbe, N., Madrono Nieto, A., Naranjo, L. G., Parker, T. A., III and Wege, D. C. 1992. Threatened Birds of the Americas: The ICBP/IUCN Red Data Book. Third edition, part 2. International Council for Bird Preservation, Cambridge.

Howell, S. N. and Webb, S. 1992. A little-known cloud forest in Hidalgo, Mexico. Euphonia 1: $7^{-11 .}$ ICBP (1992) Putting biodiversiy on the map: priority areas for global conservation. International Council for Bird Preservation, Cambridge.

Johnsgard, P. A. 1988. Quails, Partridges and Francolins of the World. Oxford University Press, Oxford.

two criteria resulted in the promotion of action for taxa which inhabit remote islands and for which there is little, if any, information, but the widespread disruption of inherently fragile island ecosystems is great cause for concern (e.g. Bruijn's Brush-turkey Aepypodius bruijnii which is only known from 15 museum specimens). Because of the small number of megapode taxa, almost all threatened taxa have been included in the five-year plan of action: three vulnerable species and two vulnerable subspecies were not. The Megapode Action Plan presents 10 projects.

The PQF and Pheasant Specialist Groups also used the urgency criterion based on the threat category assigned. The other two criteria these groups used, however, relate to the practicality of project implementation and were based on the assumption that it was not helpful to include ambitious and all-encompassing actions that stood no chance of implementation. Consequently, feasibility and the resources necessary for candidate projects were also considered. Feasibility addressed the ease with which projects could be executed in the field, so that no 
projects were included for areas where civil unrest shows no signs of abating. Assessment of the resources available for each project was based mainly on the advice of the Specialist Group's contacts in the area concerned.

In the PQF Action Plan, two classes of project were proposed. In addition to Action Plan Project Briefs, much shorter summaries of additional projects, which are thought to be less feasible at present, have been presented. This is because the number of taxa covered by this Specialist Group makes it impossible to consider action on behalf of all taxa considered endangered or critical: examples include the isolated Moroccan subspecies of the otherwise widely distributed Double-spurred Francolin Francolinus bicalcaratus ayesha and Helmeted Guineafowl Numida meleagris sabyi. Nineteen projects are presented in this Action Plan, along with nine short summaries of additional projects.

The Pheasant Action Plan contains 25 projects which address the conservation needs of all but three of the threatened or insufficiently known species. These projects, as with those outlined in the other Action Plans, include regional surveys (e.g. field surveys in south-west China), and population monitoring and management-oriented research (e.g. Brown Eared-pheasant Crossoptilon mantchuricum in China and Palawan Peacock-pheasant Polyplectron emphanum in the Philippines). Three projects appear in both the PQF and Pheasant Action Plans, those that require survey work in Sumatra (Indonesia) and Borneo (Brunei, East Malaysia and Indonesia) and Hainan Island (China).

\section{Action Plan implementation}

The completion of these Action Plans is only the first stage in the effort to conserve these species and their habitats. Following publication it is vital to turn to the implementation of these projects and the seizing of opportunities to promote the conservation of all threatened taxa whenever they arise. These Action Plans appear to have a reasonable chance of success for three reasons.

First, the extensive consultation undertaken during their preparation has resulted in broad agreement over the identification of key projects. All three steps in the formulation of the five-year plans of action have been taken in concert with a wide range of people who are knowledgeable about these birds and their habitats, especially members of the Specialist Groups. Consequently, agreement among these specialists is likely to reflect consensus on what action is most urgently needed.

Second, wide distribution of the plans to appropriate government departments and conservation organizations is made possible through IUCN - The World Conservation Union. Its Action Plan publication series provides a means whereby information on the global status and requirements of species is brought to the attention of those who can act locally. Thus participation in the IUCN family of organizations provides the common bond between the specialists who compile these Action Plans and those who can implement them.

Finally, the active nature of these three Specialist Groups and their umbrella organization, the World Pheasant Association, suggests that the most will be made of the wide consensus obtained and of their access to conservation planners and others capable of implementing the projects. Within a year of publication, 30 of the 54 projects proposed in these three Galliformes Action Plans were 
underway and the aim of promoting action on all of them before the year 2000 is an achievable goal.

\section{Acknowledgements}

We are very grateful to the many people and organizations who have made the production of these Action Plans possible. They are far too numerous to mention here, but we list them all in the three Action Plans. We must, however, thank Roland Wirth and Ulie Seal for proposing a Conservation Assessment Workshop in the first place, and Fred Daman and Roland van Bocxstaele for hosting the meeting at Antwerp Zoo. The World Pheasant Association played the leading role throughout and provided the majority of the funding for P.M. to compile the Action Plans. Additional funds were made available by BirdLife International and the Whitley Animal Trust and support was also provided by British Airways - Assisting Conservation. We especially thank Keith Howman for his tireless help and Linette Humphrey at the Species Survival Commission for all manner of assistance. We thank an anonymous reviewer for comments that improved the manuscript.

\section{References}

Audey, A. A. (1987) Action Plan for Asian primate conservation 1987-1991. Gland, Switzerland: IUCN.

Birkan, M., Potts, G. R., Aebischer N. J. and Dowell, S. D. (eds.) (1992) Perdix VI, First International Symposium on Partridges, Quails and Francolins. Gibier Faune Sauvage 9.

Collar, N. J. (1994) Red Data Books, Action Plans, and the need for site-specific synthesis. Species 21-22: 132-133.

Collar, N. J. and Andrew P. A. (1988) Birds to watch. The ICBP world check-list of threatened birds. Cambridge, U.K.: International Council for Bird Preservation (ICBP).

Collar, N. J. and Stuart S. N. (1985) Threatened birds of Africa and related islands: the ICBP/ IUCN Red Data Book. Cambridge, U.K.: ICBP and IUCN

Collar, N. J., Gonzaga, L. P., Krabbe, N., Madroño Nieto, A., Naranjo, L. G., Parker T. A. and Wege. D. C. (1992) Threatened birds of the Americas: the ICBP Red Data Book. Third edition (part 2). Cambridge, U.K.: ICBP.

Collar, N. J., Stattersfield, A. J. and Crosby, M. J. (1994) Birds to watch 2. The world list of threatened birds. Cambridge, U.K.: BirdLife International (BirdLife Conservation Series no. 4).

Cumming, D. H. M., du Toit, R. F. and Stuart, S. N. (1990) African Elephants and Rhinos: Status Survey and Action Plan. Gland, Switzerland: IUCN.

Dekker, R. W. R. J. and McGowan, P. J. K. (1995) Megapodes. An Action Plan for their conservation 1995-1999. Gland, Switzerland: IUCN.

Delacour, J. (1977) Pheasants of the world. Second edition. Hindhead, U.K.: Spur Pub. and World Pheasant Association.

Dinesen, L., Lehmberg, T., Svendsen, J. O., Hensen, L. A. and Fjeldså, J. (1994) A new genus and species of perdicine bird (Phasianidae, Perdicini) from Tanzania: a relict form with Indo-Malayan affinities. Ibis 136: 3-11.

Ellis-Joseph, S., Hewson, N. and Green, A. (1992) Global waterfowl conservation assessment and management plan. Apple Valley, Minnesota, U.S.A.: Conservation Breeding Specialist Group. 
Giminez-Dixon, M. and Stuart, S. (1993) Action plans for species conservation, and evaluation of their effectiveness. Species 20: 6-10.

Groombridge, B. (1994) 1994 IUCN Red List of threatened animals. Gland, Switzerland and Cambridge, U.K.: IUCN.

International Council for Bird Preservation (1992) Putting biodiversiy on the map: priority areas for global conservation. Cambridge, U.K.: ICBP.

Jones, D. N., Dekker, R. W. R. J. and Roselaar, C. S. (1995) The Megapodes. Oxford: Oxford University Press.

King, W. B. (1978-9) Red Data Book, 2: Aves. Second edition. Morges, Switzerland: IUCN.

Mace, G. M. and Lande, R. (1991) Assessing extinction threats: toward a re-evaluation of IUCN threatened species categories. Conserv. Biol. 5: 148-157.

Mace, G. M., Collar, N., Cooke, J., Gaston, K., Ginsberg, J. Leader-Williams, N., Maunder, M. and Milner-Gulland, E. J. (1992) The development of new criteria for listing species on the IUCN Red List. Species 19: 16-22.

McGowan, P. J. K., and Garson, P. J. (1995) Pheasants: status survey and conservation action plan 1995-1999. Gland, Switzerland: IUCN.

McGowan, P. J. K., Carroll, J. P. and Ellis, S. (1994) Galliformes conservation assessment. Apple Valley, Minnesota, U.S.A.: Conservation Breeding Specialist Group.

McGowan, P. J. K., Dowell, S. D., Carroll, J. P. and Aebischer, N. J. (1995) Partridges, Quails, Snowcocks, Francolins and Guineafowl: status survey and conservation action plan 1995-1999. Gland, Switzerland: IUCN.

Mittermeier, R. A., Konstant, W. A., Nicoll, M. E. and Langrand, O. (1992) Lemurs of Madagascar: an action plan for their conservation: 1993-1999. Gland, Switzerland: IUCN.

Oates, J. F. (1986) Action plan for African primate conservation 1986-1990. Gland, Switzerland: IUCN.

Santiapillai, C. and Jackson, P. (1990) The Asian Elephant: an action plan for its conseroation. Gland, Switzerland: IUCN.

Sibley, C. G. and Ahlquist, J. E. (1990) Phylogeny and classification of birds: a study of molecular evolution. New Haven and London: Yale University Press.

Sibley, C. G. and Monroe, B. L., Jr. (1990) Distribution and taxonomy of birds of the world. New Haven and London: Yale University Press.

Toone, B., Ellis, S., Wirth, R. Byers, A. and Seal, U. (1993) Conservation assessment and management plan for Pigeons and Doves. Apple Valley, Minnesota, U.S.A.: Conservation Breeding Specialist Group.

Vincent, J. (1966-1971) Red Data Book, 2: Aves. Morges, Switzerland: IUCN.

\section{P. McGOWAN}

Ecology and Research Group, Biology Department, The Open University, Walton Hall, Milton Keynes MK7 6AA, U.K. (Current address: Ecoscope Applied Ecologists, 9 Bennell Court, Comberton, Cambridge $\mathrm{CB}_{3} 7 \mathrm{DS}, \mathrm{U.K}$.)

R. W. R. J. DEKKER

Nationaal Natuurhistorisch Museum, P.O. Box 9517, 2300 RA Leiden, The Netherlands

\section{S. DOWELL}

School of Biological and Earth Sciences, Liverpool John Moores University, Byrom Street, Liverpool L3 $3 A F$, U.K.

\section{P. GARSON}

Department of Agricultural and Environmental Science, The Ridley Building, The University of Newcastle-upon-Tyne, Newcastle-upon-Tyne NEI $7 R U$, U.K. 